\title{
Investigation of the Relationship of Brand Personality, Subjective Norm and Perceived Control on Consumers' Purchase Intention of Organic Fast Food
}

\author{
Charraz Othman ${ }^{1} \&$ Muhammad Sabbir Rahman ${ }^{2}$ \\ ${ }^{1}$ Graduate School of Management, Multimedia University, Cyberjaya, Malaysia \\ ${ }^{2}$ Faculty of Languages and management, International Islamic University Malaysia, Jalan Gombak, Selangor \\ Darul Ehsan, Kuala Lumpur, Malaysia \\ Correspondence: Charraz Othman, Graduate School of Management, Multimedia University, Cyberjaya, \\ Malaysia. E-mail: charraz2012@yahoo.com
}

Received: February 21, $2014 \quad$ Accepted: March 20, $2014 \quad$ Online Published: April 16, 2014

doi:10.5539/mas.v8n3p92

URL: http://dx.doi.org/10.5539/mas.v8n3p92

\begin{abstract}
Organic fast food among the Malaysian consumers is an emerging theme of discourse. As more people are eating foods bought from fast food restaurants, this eating out lifestyle further heightened the problems of unhealthy eating and unbalanced diets (Azlina et al., 2011). So, to help consumers improve their personal wellness, fast food restaurants should consider various organic meals into their extended services. Indeed, this work intends to weigh into the proposed factor (TPB constructs; subjective norm and perceived dominance and brand personality dimensions; sincerity, excitement, competence, sophistication and ruggedness) towards purchase intention of organic fast food in Malaysian perspective. The outcomes distinguish that three of the factors have a significant positive association with organic fast food intention to purchase normally, sincerity, competence and sophistication. Hence, the outcome proposed that the strongest ingredients in this relation are sincerity. Therefore, the researchers agreed that fast food operators may successfully incorporate brand personality variables such as sincerity, competence and sophistication to influence on the formation of customers' intention of organic fast food. Hence, this study successfully develop theoretical and pragmatic aspects to discover the purchase intention of organic fast food on the perspective of Malaysian consumers'.
\end{abstract}

Keywords: organic food, fast food, brand personality, green purchase intention, subjective norm, perceived behavioural control, theory of planned behaviour (TPB)

\section{Introduction}

Nowadays, a hundred millions of people without giving a much thought of their purchases bought a fast food every day (Janet, 2008). Jill (2004) stated, fast foods as a broad term used for a limited menu of foods that provide themselves to production-line techniques and products such as burgers, pizzas, chicken or sandwiches tend to specialize by suppliers. Meanwhile, Ehsan (2012) defined the fast food market as the sale of food and drinks for immediate consumption either on the premises or in designated eating areas shared with other food service operators or for consumption elsewhere. Mashhadi (2012) indicated that the fast food is low price, fast service and suitable places for eating. Hence, fast food consumption is getting popular, especially with younger people (Ehsan, 2012). Nonetheless, when fast food is growing, diet food consumption also growing in popularity through rising health awareness among consumers (Chang \& Roth, 2001) thereby, the phenomenon of consuming organic food has emerged since people are starting to be cognizant of the importance of eating a healthy food in their daily life (Follows, 2000).

Asian eating habits are changing to emulate those of the West since the coming of globalization and this is why the use of fast food is likewise on the rise (SMEDA, 2006). Healthy lifestyle highlighted the slogan; "back to nature" that has become a cause for universal order. This tie is based that everything coming from nature is good and advantageous and also ensures an existence of equilibrium between human and nature (Chang \& Roth, 2001). According to Budi Suprapto (2012), organic food has been accepted in Malay since around year 1992. National Organic Standards Board of the U.S. Department of Agriculture (USDA, 2000) concluded that the organic food is a variety of agricultural products that can produced organically, including produce of grains, meat, poultry, 
eggs, dairy products and processed food products as it must be produced without the use of modern synthetic inputs such as sewer-sludge fertilizers, more synthetic fertilizers and pesticides, genetic industrial (biotechnology), hormones growth, antibiotics and are not processed using irradiation, industrial solvents, or chemical food additives (Justin, 2012). Kihlberg and Risvik (2007) found, the organic food tastes better than conventional by the bulk of organic consumers. Moreover, Chen (2009) stated that the organic foods usually contain less harmful additives and more nutrients than conventional foods and they hold no other danger of food intoxication. Hence, additives in organic food products are firmly controlled and restricted since it represents the difference between organic and non-organic food (Heaton, 2002).

The worldwide marketplace for organic food reaches US\$69.2 billion, compared to the previous year, which is up US\$4 billion in 2011 as stated by Research Institute of Organic Agriculture (FiBL, 2012) while in Malaysia organic market is comparatively young. Nevertheless, the need for organic food is dramatically increased in Malaysia since the changes in consumers' lifestyle and eating pattern to choose the intellectual nourishment that is healthy, eco-friendly and concerns towards food consumption and environmental issues (Zeinab, 2012). Consumers in Malaysia become more health conscious of their foods in daily life (Jane, 2012) since they have found out some lack in the conventional food safety (Shaharudin, Pani, \& Suhardi, 2010).

Thus, this study describes and reviews the TPB model (Theory of Planned Behaviour) in predicting individual' intention to execute a particular behaviour. Furthermore, as a means to expand the original TPB model, we investigated the added amount of brand personality into the TPB construct to measure the intention to purchase of organic fast food by Malaysian consumers. The brand personality is considered to be an indispensable piece of fast-food restaurant business that defined as a "branded convenience food" (Suvenus, 2009). The brand personality theory is founded on the idea that in guild to render substance to the product, people attaches human characteristics to a brand, thereby providing managers anticipate on this feeling by giving these human characteristics to their ware in their merchandising schemes. Above all this research investigated the impact of subjective norm, perceived control, sincerity, excitement, competence, sophistication, ruggedness and purchase intention on organic fast food that is put on to flourish in the Malaysian market.

\section{Theoretical Background and Hypothesis Development}

Purchase intention as point out by Shaw and Constanzo (1983), is a good predictor for behaviour (Aertsens, Verbeke, \& Huylenbroeck, 2011) while Ajzen and Madden (1986) stated that intention variable plays an crucial role toward behaviour because intention is considered as a mediator of motivational factors that have an impact on a behavior (Ajzen, 1991). As Organic food production and buying (behaviour) interest has increased in recent years among the consumers, therefore, several empirical studies on this market have been tackled since the organic food market has set about growing trend (Anssi, 2005).

As Ferber and Priskie (1965) point out, the intention-purchase relationship has attracted many of empirical studies highlighting significant inconsistencies between purchase intention and purchase behavior (Tirtiroglu \& Elberk, 2008). Moreover, Chong (2013) found that organic purchase intention is conceptualized as the possibility and willingness of an individual to give preference to products that having eco-friendly type over other conventional products in their buying consideration. Organic purchasing is defined as purchasing goods and services which have less harmful for environmental and human health (Lee, 2009) while as stated by (Mostafa, 2007), organic purchase behaviour relates to the use of the products and services which are useful to the environment, recyclable and responsive to ecological concerns. Sheppard (1988) point out that the relation between intentions and activities has been composed with respect to many different types of behaviours as cited in (Anssi, 2005). Thus, the intentions to purchase organic fast food are significant predictors of actual behaviour in this study.

Fisbein and Ajzen (1975) asserts, using planned behaviour theory, the word of intention can be explained which assumes that humans always have a purpose in acting. Thus, since the purchase intention helps most organic food producers to key out the behaviour of customers and their perceptions into the merchandise then it is something crucial to concentrate on (Magistris, 2008) since intention shows how tough a person is to make some attempts. Studies (Anssi, 2005) have demonstrated that the intentions of buying organic food to the behaviour is positive and has been proven that the efficacy of the TPB of organic food consumption. In addition, TPB more recently often been applied in the range of food choice and to model organic food selection (Magistris, 2008). While Chen (2007) studied that subjective norm and perceived control significantly boost the consumer's intention to buy organic foods.

While brand personality is an attractive and appealing concept in the market today that described it as one of the core dimensions of the brand identity and perhaps as the closest variable to the consumers' decision making 
process of buying and it also refers to the thought that relationships are imperative in community life (Rajagopal, 2006). Otherwise, Aaker (1997) defined Brand personality as "the circle of human characteristic associated with a trade name" and it's conceived to be an important element for the success of the trade name in terms of taste and choice (Rajagopal, 2006). Hence, customers' attitudes and behaviours towards the stigma will reflect on brand, personality which may regard on the consumer tendency in connection with the brand and ultimately affect purchase likelihood (Aaker, 1996). So, the factors that contribute to describe the purchase behaviour of environment-friendly merchandise, especially organic food, still need to be further explored. Figure 1 presents the theoretical framework of the study.

\subsection{Subjective Norm}

Subjective norms on customer intention are understood as the external factors' effects and refers to the "an important individuals or groups referent that likelihood given either approve or disapprove to performing a behaviour" (Ajzen, 1991). Taylor (1999) reported that a subjective norm is a proficient interpreter of behaviour when an individual's actions affect some other person's benefit. Conversely, Lapinski, Rimal, DeVries and Lee (2007) establish that the issue of subjective norms is insignificant when only one individual affected in the arriving at a selection. Withal, the subjective norms' role was obscure in a previous survey of purchase design and behaviour of organic food, especially regards to forming the behaviour (Ajzen, 1991). Recent surveys also point to the impact of "subjective norm" on the attitude towards buying organic food (Aertsens, Mondelaers, \& Van Huylenbroeck, 2009). According to Eagly et al. (1993) subjective norm perform a behaviour with a consumer's motivation to construct the first moments of an important person such as family, friends and significant others (Yangui, Font, \& Gil, 2013). Rather, consumers will have more intention on purchasing organic foods if the significant people of them think organic foods are safe. Conversely, they will have poorer intention if those people important for they believe organic foods are unfit. Therefore, the consumers' intention to purchase organic fast food will increase when the intention of important person surrounding them rises since the organic foods are supposed as healthier and environmentally friendly rather than conventional foods (Chong, 2013).

According to Ajzen (2006), subjective norm is a person's social pressure to engage in behaviour and it is said to be decided by the full set of reachable normative beliefs regarding the potentials of individual referents (e.g. Family or friends). Chen (2007) point out; applied to organic food consumption; it is positively related between the consumers' intention of organic food and their subjective norm. Conversely, Anssi Tarkiainen (2005) stated, subjective norm and intention to buy organic has no direct way. While, Christopher Armitage (2001) explained that subjective norm have no direct effect on intention after checking on attitude and PBC (Bamberg \& Moser, 2007). However, Bamberg and Moser (2007) discover that subjective norm has no direct link with intention in a situation of pro-green behaviour. The first hypothesis of the research model is proposed as follows:

H1: Subjective norm has a positive impact on organic fast food purchase intention in Malaysia

\subsection{Perceived Control}

Perceived behavioural control (PBC) is the point of perceiving one's his ability to handle given situations towards successfully (Ajzen, 1991). Meanwhile, Bandura (1986) point out that it is concerned and judgments of what an individual can manage with anything skills one possesses not the skills an individual has since it is highly shown an individual necessary the confidence in their ability to be successful on perform the behaviour since it is determined an individual's behaviour (Swann, Chang-Schneider, \& Larsen McClarty, 2007). Other that, perceived controllable deals with the consumers' actual possibilities, i.e. external control to buy organic food while the perceived self-efficacy deals with consumers' internal control for purchasing organic food as cited in Anssi Tarkiainen (2005). Consequently, the level of PBC should raise as the individual has both access that tools is required also an information, accomplishments and opportunities to effectively utilize them.

In addition, Chong (2013) point out that the consumers' perceived difficulty and their designs to purchase organic foods related positively each other when personality behaviour becomes more potent. Therefore, according to several empirical studies Aertsens et al. (2009), income (PBC) appears to act as a significant positive role in clarifying organic food purchasing in Europe. Nevertheless, in several studies of USA, they did not find this relation to be significant as cited by (Gracia \& Magistris, 2007) while studies in Canada (Aertsens et al., 2009) set forth a positive connection between income and willingness to buy organic products, upward to a given degree of income. Lockie, Lyons and Lawrence (2002) studied, the proportion of Australians consuming organic food stands up when income upturns and the changes in organic food utilization also get up to changes in the condition of income (Riefer \& Hamm, 2008).

Meanwhile, Aertsens et al. (2009) observe a positive effect from PBC on the buying intention on organic apples, 
while this it was not significant for organic pizza. The past research of organic consumption has demonstrated that the most important causes for not buying the organic food or the lack of availability as a difficulty and organic food's relatively higher cost compared to formal ones as cited by (Aertsens et al., 2009). It is clearly not under consumers' control. Overall, intentions to purchase organic food significantly related to a combination of the attitude, (personal and subjective) subjective norms and (perceived) behavioural control while Aertsens et al. (2009) stated TPB model possibly will help explain organic food purchase intention. Therefore, the second hypothesis is determined as follows:

H2: Perceived control influences positively the intention to purchase organic fast food in Malaysia.

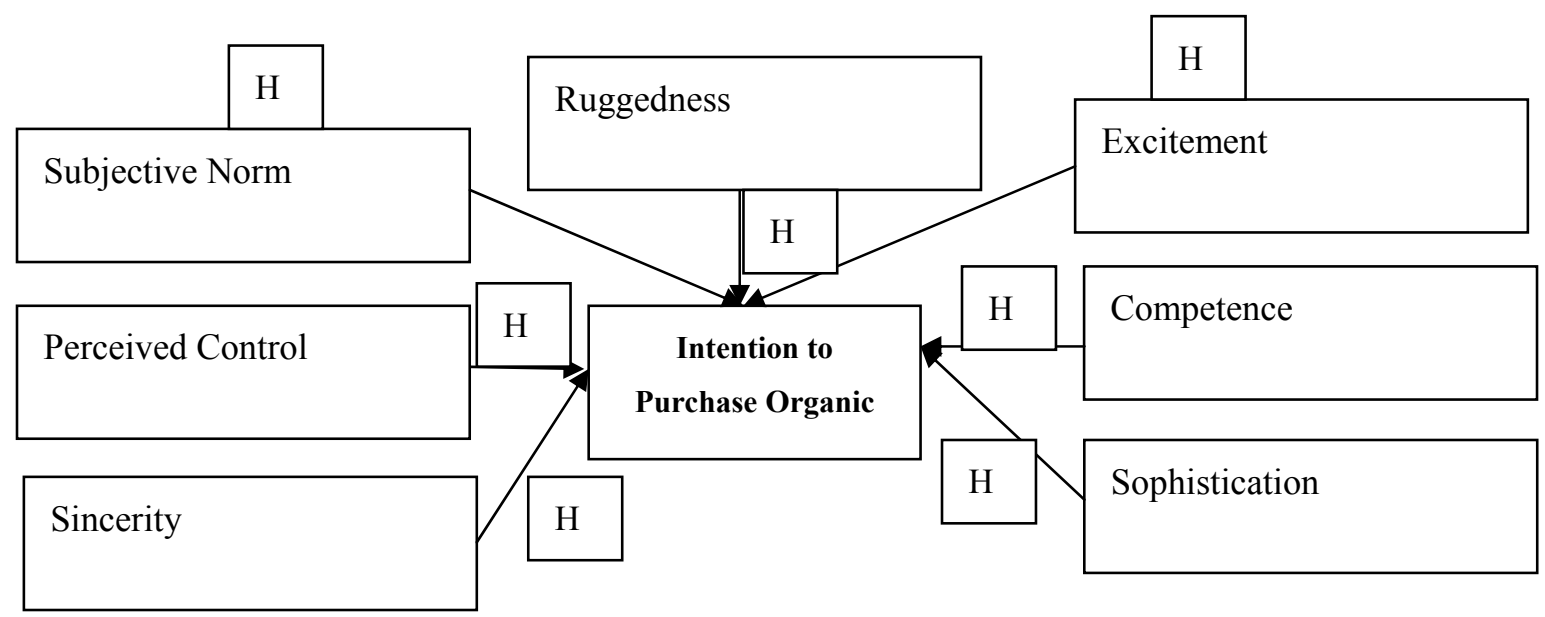

Figure 1. Research framework for organic fast food purchase intentions

\subsection{Sincerity}

According to Maehle, Otnes and Supphellen (2011), sincere brands considered a high moral while exciting brands present a chance to occurrence feelings of excitement. Therefore, a brand with sincere personality, character can make a much positive relationship than a brand with an exciting personality (Maehle et al., 2011). Brands that are presented as sincere would concern to customers in many demographics who are in search of a down-to-earth approach to the product they are purchasing.

Sincerity is a dimension that connected to concepts as warmth and acceptance which there are four different facets that have been known for sincerity: down-to-earth, honest, wholesome and cheerful (Aaker, 1997), real and sincere (Aaker, 2001).

In the other hand, sincerity also presents in agreeableness which indicates strong social orientations, cooperation and harmony seeking person as cited by Hasliza (2012) and according to Aaker (1997), nurturance, warmth, family orientation and traditionalism also are characteristics of sincere of brand personalities. Succeeding, the third hypothesis as follows:

H3: Sincerity has a positive impact on the organic fast food purchase intention in Malaysia.

\subsection{Excitement}

Excitement is defined as 'the degree of talkativeness, freedom, happiness and energy shown in a brands' personality trait (Lin, 2010). Hence, it takes a sense of adventure to customers' lives, especially those who already live exciting and adventuresome lives (Jennifer, 2011). Therefore, the traits such as daring, spirited, imaginative and up-to-date may show the excitement, personality of the customer who a young and adventurous person.

Gil and Hellgren (2011) point out; an excitement is seen encapsulates concepts such as sociability, energy and activity also this dimension has four facets which are: daring, spirited, imaginative and up-to-date. It is capturing the energy and activity elements of extraversion as well as exciting and contemporary (Aaker, 2001) that represent the "tendency towards change, visionary orientations, strong intuition, creative imagination and inherent enthusiasm as cited by Hasliza (2012). Further, exciting of brand personalities convey vitality, uncommon and independence (Lin, 2010). And so, the fourth hypothesis of the research model as follows: 
H4: Excitement has a positive impact on the organic fast food purchase intention in Malaysia.

\subsection{Competence}

Aaker (1997) defines competence as the level of responsibility, purpose and patience in a brands' personality trait. Therefore, it conveys the features of dependability, intelligence, and achiever. In addition, competitive companies are trying to win with competitors for their excitement personality. For example, industries like automotive and information technology such as Apple which competes for the excitement and competency based on purchase at the same time.

Competence is a dimension connected to concepts as duty, security, dependability and achievement which similar to conscientiousness (Aaker, 2001). It delivers three different facets: reliable, intelligent and successful that are more on, task-oriented, structured and logical and enables an individual to concentrate on certain facets of acting, learning and changing behaviour as well as personality related capacities as Hasliza (2012) concluded. Then, the fifth hypothesis of the research model is defined as follows:

H5: Competence has a positive impact on the organic fast food purchase intention in Malaysia.

\subsection{Sophistication}

As point out by Aaker (1997), sophistication is the degree of elegance and style in a brand personality attribute which presents the characteristics of upper class and charm. Instantly, customers may classify the brands and products in this brand dimension such as luxury items that are in higher categories.

Sophistication is a dimension that includes traits as aspiration, glamour and sexiness and has two facets: upper class and charming as found by Aaker (2001) as well as romantic that indicate the trend of strong emotion and sensitivity of a person (Hasliza, 2012). Thus, Sophistication is ones of the ways to segment and target markets for different consumer will react differently towards a special view. The sixth hypothesis of the proposed model is defined as follows:

H6: Sophistication has a positive impact on the organic fast food purchase intention in Malaysia.

\subsection{Ruggedness}

As stated by Jennifer (2011), ruggedness brand personality is associated with camping equipment and vehicles which suitable for carrying livestock and farm equipment. So, the characteristic of hardness such as outdoorsy, tough, strong and rugged like to purchase goods marketed with ruggedness.

According to Gil and Hellgren (2011), ruggedness in whatever manner is regarded as strength, masculinity and is presenting a glamorized view of ideals that there are two different facets for this dimension: outdoorsy lifestyle and tough also masculine and western (Aaker, 2001) that indicate a reliable, strict and structured individual (Hasliza, 2012). All the same, this dimension is suitable for an American to look into brand personality dimensions according to suitable culture.

In other hand, in certain community market (Aaker, 2001) since it seems to be more suited for the Malaysian community which is perceived as westernized from the findings in several literature reviews thus the original brand personality dimensions is starting to be applied in this conceptual research (Hasliza Hassan, 2012). Lastly, the hypothesis of the proposed model is defined as follows:

H7: Ruggedness has a positive impact on the organic fast food purchase intention in Malaysia.

\subsection{Theory of Planned Behaviour (TPB) Model Brand Personality Model}

In this work, we applied Theory of Planned Behaviour (TPB) as our theoretical contribution to understand and predict fast food consumption behaviour (Ajzen, 1991). To predict the intention to purchase organic fast food among Malaysian consumers' this research applied three primary antecedents namely, subjective norm (perceived social pressure from one's immediate environment to perform or not perform the behaviour) (Ajzen \& Fishbein, 1980) and perceived control(ability)that states the people's perceptions of their skill to accomplish a given behaviour) (Ajzen, 2006; Anssi, 2005).

In summation, the scale of brand personality (1997) is employed as the framework to explain the variables of personality that will be applied to define the personality towards an organic fast food eatery. Therefore, the theoretical framework has been widely employed by other researchers and Aaker (1997) which her goals were to produce a theoretical framework of dimensions that could be able to measure brand personality while being honest, valid and useful when making generalizations across product classes. The five dimensions identified in the survey were: Sincerity, Excitement, Competence, Sophistication and Ruggedness. 


\section{Methods}

\subsection{Data Collections and Sample}

This research gathered data from 169 Malaysian consumers (63 males and 106 females), which were contributed a response rate of 56.0 percentage (300 questionnaire was distributed). Under the racial perspective majority number of respondents grouped under (58.6\%) of Malay. Roughly 20.0 percent of the respondents were Chinese followed by Indians. Meanwhile, the majority (around 80\%) of the respondents was aged between 25 to 44 years while the respondents above 45 years old, around (3\%). However, more than $(80 \%)$ of the respondents were employed, full-time $(60.9 \%)$, part-time $(7.7 \%)$ and self-employed $(17.8 \%)$. It was found that the bulk of the respondent's income were between RM3001 to RM4000 (52.1\%). Thus, based on the respondent's answers, consumers moderately agreed that the organic fast food has the characteristics of sincerity.

Table 1. Demographic profiles

\begin{tabular}{lcc}
\hline \multicolumn{1}{c}{ Respondents } & Frequency (n) & Percentage (\%) \\
\hline Gender & & \\
\hline Male & 63 & 37.3 \\
Female & 106 & 62.7 \\
\hline Ethnicity & & \\
\hline Malay & 99 & 58.6 \\
Chinese & 33 & 19.5 \\
Indian & 26 & 15.4 \\
Sabahan & 7 & 4.1 \\
Sarawakian & 4 & 2.4 \\
\hline Age & & \\
\hline 18 to 24 & 21 & 12.4 \\
25 to 34 & 83 & 49.1 \\
35 to 44 & 58 & 34.3 \\
45 to 54 & 4 & 2.4 \\
Above 55 & 3 & 1.8 \\
\hline Income & & \\
\hline Less than RM1000 & 23 & 13.6 \\
RM1001 to RM2000 & 13 & 7.7 \\
RM2001 to RM3000 & 36 & 21.3 \\
RM3001 to RM4000 & 88 & 52.1 \\
RM4001 to RM5000 & 6 & 3.6 \\
Over RM5001 & 3 & 1.8 \\
\hline
\end{tabular}

\subsection{Instrument Development and Data Analysis}

For raising the appropriate result, the questionnaire was designed in three sections: section A, B and C. The source section (Section A) contained questions about demographics and socioeconomic (e.g., age, gender, race, marital status, employment status and income) and the second section (Section B) contained questions about consumers' knowledge of organic merchandise. Final part (Section C) gauges the variety, namely; subjective norm, perceived control, brand personality dimensions, namely; sincerity, excitement, competence, sophistication and ruggedness as well as an intentions which each variable was assessed along a five-point scale Likert style. The questionnaires adapted from several of previous study.The questionnaire was adapted from Aaker (1997) and the Theory of Planned Behaviour (TPB) by Ajzen (1991) and modified based on the position of Malaysian environment. The statements for subjective norm and perceived control were adapted from the 
existing TPB construct scales (Kim \& Han, 2010) and have been evolved based on the model questionnaire proposed by Ajzen (Ajzen \& Fishbein, 1980). All responses were completed on a five-point Likert scale. In addition, the brand personality scale was adapted from the previous research (Lee, 2009; Aaker, 1997). However, several of the items excluded from this study since there are irrelevant for this current research. Thereof, 27 points would be utilised to measure brand personality in this workplace. Intention to purchase was adapted from existing scales developed by Kim and Han (2010). The detail items of construct are provided in the Appendix. To test the above mentioned hypothesis this research applied multiple regression to examine the influence of the independent variables that bear on the metric of the dependent variable as stated by Sekaran and Bougie (2010). In this study, multiple regression analysis was applied to analyse the effect of subjective norm, perceived control, sincerity, excitement, competence, sophistication and ruggedness towards the intention to purchase organic fast food. The result from the multiple regression output revealed that three variables are significant to the purchase intention organic fast food while four was not significant. Therefore, the hypothesis result shows that all the variables are not significantly supported except for sincerity, competence and sophistication which are $0.00,0.05$ and 0.04 respectively. The multiple regression analysis based on the linear relationship between independent variables and a dependent variable. Thus, the correlation analysis for autonomous and dependent variable of hypothesis shows there is a high significant correlation between sincerity $(0.78)$, competence $(0.76)$ and excitement (0.73) while perceived control (0.42), subjective norm and ruggedness $(0.56)$ induce a lower correlation on organic fast food intention.

Table 2. The result of the main effects in the proposed model

\begin{tabular}{lcc}
\hline \multirow{2}{*}{ Variables } & TPB constructs \& Brand Personality Dimensions- & Purchase Intention \\
\cline { 2 - 3 } & $\boldsymbol{B}$ & $\boldsymbol{P}$ \\
\hline Subjective norm & 0.124 & 0.172 \\
Perceived control & 0.040 & 0.567 \\
Sincerity & 0.340 & 0.004 \\
Excitement & 0.221 & 0.169 \\
Competence & 0.262 & 0.045 \\
Sophistication & 0.262 & 0.038 \\
Ruggedness & -0.300 & 0.056 \\
\hline Adjusted $R$-Squared $=0.646$ & & \\
\hline
\end{tabular}

a. Dependent Variable: Purchase intention.

Table 2 depicts the result of regressions among seven variables against the dependent variable. Grounded on the data presented above, the $\mathrm{b}$ value shows the kinship between the predictor and the final result. Therefore, the regression equation can be formalised as follows:

$$
\mathrm{Y}=\mathrm{a}+\mathrm{b} 1 \mathrm{X} 1+\mathrm{b} 2 \mathrm{X} 2+\mathrm{b} 3 \mathrm{X} 3+\mathrm{b} 4 \mathrm{X} 4+\mathrm{b} 5 \mathrm{X} 5+\mathrm{b} 6 \mathrm{X} 6+\mathrm{b} 7 \mathrm{X} 7+\mathrm{e}
$$

All the result extracted from Table 2 indicates that the positive relationship between independent variables and purchase intention of consumers on purchasing organic fast food. However, Ruggedness was found less influence towards intention to purchase organic fast food.

Meanwhile, Sincerity was found most influence when purchase organic fast food in Malaysia that (34\%) in aggregate. Furthermore, the p-values for the all predictors are more than 0.05 , except for sincerity $(0.00)$, Competence (0.05) and Sophistication (0.04). Based on the result above the subjective norm, perceived control, excitement and ruggedness are not significantly predicting the variability of organic purchase intention in Malaysia. Whereas, Sincerity variable $(\beta=0.340)$ attained the highest effects on organic fast food purchase intention followed by competence and sophistication $(\beta=0.262)$.

\section{Managerial Implication}

The prediction of organic fast food purchase intention from TPB variables was similar to the levels of prediction obtained from other behavioural research (Armitage, Norman, \& Conner, 2002). Thus, the results revealed that perceived control remained weaker predictor of purchase intentions. From the research the perceived control variable found no significant positive influence on purchase intention of organic fast food (Christopher, 2001), 
subjective norm often as the weakest component among the TPB constituents that answerable for the described variations in pattern.

As, for instance, Thompson, Haziris and Alekos (1994) found that subjective norm is a poor predictor of behavioural intention in food choice. Therefore, in order to draw the consumers to purchase organic fast food, the perceptions of the people who are vital to them must be influenced. In this case, sellers of organic food should keenly find techniques to raise environmental alarms (e.g., promoting pro-organic campaigns and pro-healthy fast food). Moreover, intentions to purchase organic fast food, mostly are found out by the positive approach in which referents as family, kin or friends that considered on intention to purchase organic fast food. Thus, in lodge to improve the influence such referents, the vendors should find ways to provide the certain organic features of their products and service to the residential area.

It can be caused from various information sources like television, website, magazines, brochures and etc. into organic fast food perceptions. Moreover, this study also recommends that several of the brand personality constructs such as sincerity, competence and sophistication are sufficient for explaining intentions to purchase organic fast food.

Therefore, brand personality variables apparently can provide significant force for consumer purchase intention formation on organic fast food perspectives. Well, in order to draw the consumers to purchase organic fast food based on the perceptions of the masses who are significant to them, managers and vendors should look for ways to determine the reference group of the consumers such as promoting pro-healthy fast food through advertising endorser. Thus, fast food companies may recommend and promote products, namely organic fast food in order to make a differential product image and influence on consumer purchase behaviour because it can produce a recommendation and endorsement effect and build customers' reliability on organic fast food purchase intention.

\section{Conclusion and Further Research}

In Malaysia, the organic fast food is weighed at the introductory level where not many people are concerned about. The interest to conduct this study is to possess a better understanding of Malaysian consumers' purchase intention in organic fast food purchasing context.

Overall, in society to encourage consumers' willingness to purchase organic fast food, a several useful strategy for marketing communication campaigns must be designed with concern as there are no scientific facts that organic food products are healthier or more nutritious than conventional food (Magistris, 2008). In Malaysia the industry of organic fast food, perhaps too young since there are only a few restaurants employed this concept of the eatery.

Hence, the industry of organic fast food needs more brand exposures in order to create the brand awareness in consumer minds. The exposures can be managed by focusing in marketing programs to increase customer awareness in the surrounding residential areas. Further enquiries are needed to substantiate the significance of the societal force and groups of reference on purchase intention of organic fast food in the restaurant setting. This study successfully incorporates brand personality variables such as sincerity, competence and sophistication to determine the purchase intention of the organic fast food.

\section{References}

Aaker, J. L. (1997). Dimensions of Brand Personality. Journal of Marketing Research, XXXIV, 347-356. http://dx.doi.org/10.2307/3151897

Aertsens, J., Verbeke, W., Mondelaers, K., \& Van Huylenbroeck, G. (2009). Personal determinants of organic food consumption: a review. British Food Journal, 111(10), 1140-1167. http://dx.doi.org/10.1108/00070700910992961

Ahmad, S. N. B., \& Juhdi, N. (2010). Organic Food: A Study on Demographic Characteristics and Factors Influencing Purchase Intention Among Consumers in Klang Valley Malaysia. International Journal of Business and Management, 5(2), 1-14.

Ajzen, I. (1991). The Theory of Planned Behavior. Organizational Behavior and Human Decision Processes, 50 , 179-211. http://dx.doi.org/10.1016/0749-5978(91)90020-T

Armitage, C., Norman, P., \& Conner, M. (2002). Can the theory of planned behaviour mediate the effects of age, gender and multidimensional health locus of control? British Journal of Health Psychology, 7, 299-316. http://dx.doi.org/10.1348/135910702760213698 
AzlanAmran, G. Y. (2012). Determinants of Behavioral Intention on Sustainable Food Consumption Among Consumers' of Low Income Group: Empirical Evidence From Malaysia. WEI International European Academic Conference Proceedings (pp. 84-93).

Bamberg, S., \& Moser, G. (2007). Twenty years after Hines, Hungerford, and Tomera: A new meta-analysis of psycho-social determinants of pro-environmental behaviour. Journal of Environmental Psychology, 27, 14-25. http://dx.doi.org/10.1016/j.jenvp.2006.12.002

Biemans, S. Z. (2009). Factors underlying consumption of organic food in the opinion of Polish consumers. Agronomy Research, 7(2), 768-774.

Chakrabarti, S. (2010). Factors influencing organic food purchase in India - expert survey insights. British Food Journal, 112(8), 902-915. http://dx.doi.org/10.1108/00070701011067497

Chang, G., \& Roth, C. B. (2001). Structure of MsbA from E. coli: A homolog of the multidrug resistance ATP

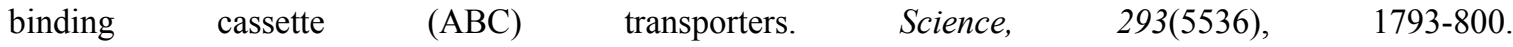
http://dx.doi.org/10.1126/science.293.5536.1793

Chen, M. F. (2007). Consumer attitudes and purchase intentions in relation to organic foods in Taiwan: Moderating effects of food-related personality traits. Food Quality and Preference, 18, 1008-1021. http://dx.doi.org/10.1016/j.foodqual.2007.04.004

Chen, M. F. (2009). Attitude toward Organic Food Among Taiwanese as related to Health Consciousness, Environmental Attitudes and the Mediating Effects of a Healthy Lifestyle. British Food Journal, 111(2), 165-178. http://dx.doi.org/10.1108/00070700910931986

Chong, C. W. (2013). Factors Influencing on Purchasing Behaviour of Organic Foods. Human and Social Science Research, 1(2), 93-104.

Christopher, J., \& Armitage, M. C. (2001). Efficacy of the Theory of Planned Behaviour: A meta-analytic review. British Journal of Social Psychology, 471-499.

Cuza, A. I. (2012). Factors Influencing Consumption of Organic Food in Romania. The USV Annals of Economics and Public Administration, 12(1), 15.

Danseh, S. Y. S., Hashemnia, S., \& Sefidmazgi, M. R. (2012). Evaluating effective factors on customers' attitude to by green products (Case study: consumers of products with A and Benergy labels in Rasht). International Research Journal of Applied and Basic Sciences, 3(11), 2316-2322.

Dardak, R. A., Abidin, A. Z. Z., \& Ali, A. K. (2009). Consumers' perception, consumption and preference on organic product: Malaysian Perspective. Economic and Technology Management Review, 95-107.

de Magistris, T., \& Gracia, A. (2008). The decision to buy organic food products in Southern Italy. British Food Journal, 110(9), 929-947. http://dx.doi.org/10.1108/00070700810900620

DellaVigna, S., Moretti, E., \& Pathania, V. (December 2008). The Effect of Fast Food Restaurants on Obesity.

Dolatabadi, H. R., Kazemi, A., \& Rad, N. S. (November 2012). The Impact of Brand Personality on Product Sale through Brand Equity (Case Study: Cosmetic Products Retailers). International Journal of Academic Research in Business and Social Sciences, 2(11).

Ehsan, U. (2012). Factors important for the selection of fast food restaurants: an empirical study across three cities of Pakistan. British Food Journal, 114(9), 1251-1264. http://dx.doi.org/10.1108/00070701211258808

Essoussi, L. H., \& Zahaf, M. (2008). Decision making process of community organic food consumers: an exploratory study. Journal of Consumer Marketing, 25(2), 95-104. http://dx.doi.org/10.1108/07363760810858837

Follows, S. B., \& Jobber, D. (2000). Environmentally responsible purchase behaviour: A test of a consumer model. European Journal of Marketing, 34(5/6), 723-746. http://dx.doi.org/10.1108/03090560010322009

Frank, B. (2012). The formation of consumer attitudes and intentions towards fast food restaurants: How do teenagers differ from adults? Managing Service Quality, 22(3), 260-280. http://dx.doi.org/10.1108/09604521211230987

French, D. P., Sutton, S., Hennings, S. J., Mitchell, J., Wareham, N. J., Griffin, S., ... Kinmonth, A. L. (2005). The Importance of Affective Beliefs and Attitudes in the Theory of Planned Behavior: Predicting Intention to Increase Physical Activity. Journal of Applied Social Psychology, 35(9), 1824-1848. http://dx.doi.org/10.1111/j.1559-1816.2005.tb02197.x 
Gotschi, E., Vogel, S., \& Lindenthal, T. (2007). High school students' attitudes and behaviour towards organic products: survey results from Vienna. Department of Economics and Social Sciences, 2-18.

Gracia, A., \& Magistris, T. De. (2007). Organic food product purchase behaviour: A pilot study for urban consumers in the South of Italy. Spanish Journal of Agricultural Research, 5(4), 439-451. http://dx.doi.org/10.5424/sjar/2007054-5356

Gracia, A., T. D. (2007). Organic Food Product Purchase Behaviour: A pilot study for urban consumers in the South of Italy. Spanish Journal of Agricultural Research, 5(4), 439-451. http://dx.doi.org/10.5424/sjar/2007054-5356

Haghiria, M., Hobbs, J. E., \& McNamara, M. L. (2009). Assessing Consumer Preferences for Organically Grown Fresh Fruit and Vegetables in Eastern New Brunswick. International Food and Agribusiness Management Review, 12(4).

Hair Jr, J. F., Barry, J., \& Babin, R. E. (2009). Multivariate Data Analysis (7th ed.). Prentice Hall.

Hassan, H., \& Rahman, M. S. (June 2012). The Impact of Hypermarket Corporate Brand Extensions on Brand Personality: A Conceptual Analysis of Malaysian Market. International Journal of Business and Management, 7(12).

Heaton, S. (2002). Organic Food and Health: The Evidence. Compass Internet Ltd. Retrieved from The Positive Health Online website: http://www.positivehealth.com

Hoogendam, J. B. (2011). The role of social identity and attitudes toward sustainability brands in buying behaviors for organic products. Journal of Brand Management, 18(9), 697-708. http://dx.doi.org/10.1057/bm.2011.3

Jill Davies, G. J. L. (2004). Fast food: dietary perspectives. Nutrition \& Food Science, 34(2), 80-82. http://dx.doi.org/10.1108/00346650410529050

Khare, A., \& Handa, M. (2009). Role of individual self-concept and brand personality congruence in determining brand choice. Innovative Marketing, 5(4), 63-71.

Kihlberg, I., \& Risvik, E. (2007). Consumers of organic foods - value segments and liking of bread. Food Quality and Preference, 18(3), 471-481. http://dx.doi.org/10.1016/j.foodqual.2006.03.023

Kim, Y. J., \& David Njite, M. H. (2012). The Role of Emotion in Consumers' Intentions to Select Eco-Friendly Restaurants: Broadening and Deepening the Theory of Planned Behaviour (pp. 4-36).

Kuhar, A., \& Juvancic, L. (2010). Determinants of purchasing behaviour for organic and integrated fruits and vegetables in Slovenia. Agricultural Economic Review, 11(2), 70-83.

Kumar, B. (2012). Theory of Planned Behaviour Approach to Understand the Purchasing Behaviour for Environmentally Sustainable Products. Indian Institute of Management, 2-43.

Kumar, R. (2011). Research Methodology: A step-by-step guide for beginners. London: SAGE Publications.

Lapinski, M. K., Rimal, R. N., DeVries, R., \& Lee, E. L. (2007). The Role of Group Orientation and Descriptive Norms on Water Conservation Attitudes and Behaviors. Health Communication, 22(2), 133-142. http://dx.doi.org/10.1080/10410230701454049

Lea, E., \& Worsley, T. (2005). Australians' organic food beliefs, demographics and values. British Food Journal, 107(11), 855-869. http://dx.doi.org/10.1108/00070700510629797

Lee, J. W. (2009). Relationship Between Consumer Personality and Brand Personality as self-Concept: From the Case of Korean Automobile Brands. Academy of Marketing Studies Journal, 13(1).

Lin, L. (2010). The relationship of consumer personality trait, brand personality and brand loyalty: An empirical study of toys and video games buyers. Journal of Product \& Brand Management, 19(1), 4-17. http://dx.doi.org/10.1108/10610421011018347

Lockie, S., Lyons, K., \& Lawrence, G. (January 2002). Eating 'Green': Motivations Behind Organic Food Consumption in Australia. European Society for Rural Sociology, 42(1), 24-40.

Lončarić, R., Lončarić, Z., \& Zmaić, K. (2009). Computer model for predicting organic food consumer behavior in Croatia. 4th Aspects and Visions of Applied Economics and Informatics, 419-426.

Lückerath, B. (October 2010). How Brands become People-A Study on the Impact of Brand Personality on Brand Value. Copenhagen Business School, 75, 170-819. 
Maehle, N., Otnes, C., \& Supphellen, M. (2011). Consumers' Perceptions of the Dimensions of Brand Personality. Journal of Consumer Behaviour, 10(5), 290-303. http://dx.doi.org/10.1002/cb.355

Malik, M. E., \& Naeem, B. (2012). Aaker's Brand Personality Framework: A Critical Commentary. Journal of Basic and Applied Scientific Research, 11992-11996.

Mashhadi, A. H. (2012). Impact of External Environment on the Performance of the Fast Food Industry. International Journal of Management, Economics and Social Sciences, 1(1), 19-25.

Mohd Rizaimy Shaharudin, J. J., \& Suhardi Wan Mansor, S. J. (2010). Purchase Intention of Organic Food; Perceived Value Overview. Canadian Social Science, 6(1), 70-79.

Mondelaers, K., Verbeke, W., \& Van Huylenbroeck, G. (2009). Importance of health and Environment as Quality Traits in the Buying Decision of Organic Products. British Food Journal, 111(10). http://dx.doi.org/10.1108/00070700910992952

Morgan, G. A., Leech, N. L., Gloeckner, G. W., \& Barrett, K. C. (July 12, 2012). IBM SPSS for Introductory Statistics: Use and Interpretation. Routledge.

Mostafa, M. M. (2007). Gender differences in Egyptian consumers' green purchase be-haviour: The effects of environmental knowledge, concern and attitude. International Journal of Consumer Studies, 31(3), 220-9. http://dx.doi.org/10.1111/j.1470-6431.2006.00523.x

Mulyanegara, R. C., Tsarenko, Y., \& Anderson, A. (Jan-Feb 2009). The Big Five and brand personality: Investigating the impact of consumer personality on preferences towards particular brand personality. Journal of Brand Management, 16(4), 234-247. http://dx.doi.org/10.1057/palgrave.bm.2550093

Niessen, J. H. (June 16-20, 2008). Identifying the gap between stated and actual buying behaviour on organic products based on consumer panel data. 16th IFOAM Organic World Congress, Modena, Italy, 346-349.

Nishimura, J. S., \& Tristán, O. M. (2011). Using the theory of planned behavior to predict nascent entrepreneurship. Academia, Revista Latinoamericana de Administración, 46, 55-71.

Olsen, S. O., \& Grunert, K. G. (2010). The role of satisfaction, norms and conflict in families' eating behaviour. European Journal of Marketing, 44(7/8), 1165-1181. http://dx.doi.org/10.1108/03090561011047571

Opoku, R. A., Abratt, R., Bendixen, M., \& Pitt, L. (2007). Communicating brand personality: Are the web sites doing the talking for food SMEs? Qualitative Market Research: An International Journal, 10(4), 362-374. http://dx.doi.org/10.1108/13522750710819702

Pal Kraft, J. R. (2005). Perceived difficulty in the theory of planned behaviour: Perceived behavioural control or affective attitude? British Journal of Social Psychology, 44, 479-496. http://dx.doi.org/10.1348/014466604X17533

Paul, J., \& Rana, J. (2012). Consumer behavior and purchase intention for organic food. Journal of Consumer Marketing, 29(6), 412-422. http://dx.doi.org/10.1108/07363761211259223

Pearson, D., Henryks, J., \& Jones, H. (2010). Organic food: What we know (and do not know) about consumers. Renewable Agriculture and Food Systems, 26(2), 1-7.

Peter Midmore, S. N., Anne-Marie Sherwood, D. V., \& Mette Wier, R. Z. (2005). Consumer Attitudes to Quality and Safety of Organic and Low Input Foods: A review. Quality Low Input Food, 5-67.

Phuah, K. T., Rezai, G., Mohamed, Z., \& Shamsudin, M. N. (2012). Consumers' awareness and consumption intention towards green foods. African Journal of Business Management, 6(12), 4496-4503. http://dx.doi.org/10.5897/AJBM11.1414

Pino, G., Peluso, A. M., \& Guido, G. (2012). Determinants of Regular and Occasional Consumers' Intentions to Buy Organic Food. The Journal of Consumer Affairs, Spring, 46(1), 157-169. http://dx.doi.org/10.1111/j.1745-6606.2012.01223.x

Purkayastha, S. (2009). Brand Personality: An Empirical Study of Four Brands in India. The Icfaian Journal of Management Research, 8(4).

Radman, M. (2005). Consumer consumption and perception of organic products in Croatia. British Food Journal, 107(4), 263-273. http://dx.doi.org/10.1108/00070700510589530

Raj Arora, C. S. (2009). A mixed method approach to understanding brand personality. Journal of Product \& Brand Management, 18(4), 272-283. http://dx.doi.org/10.1108/10610420910972792 
Rajagopal. (2006). Insights from research Brand excellence: measuring the impact of advertising and brand personality on buying decisions. Emerald Group Publishing Limited, 10(3), 56-65.

Rajagopal. (2007). Buying decisions towards organic products: an analysis of customer value and brand drivers. International Journal of Emerging Markets, 2(3), 236-251.

Research Institute of Organic Agriculture (FiBL). (February 22, 2012). Organic World: Global Organic Farming Statistics and News. Retrieved from http://www.organic-world.net

Rezai, G., Mohamed, Z., \& Shamsudin, M. N. (2011). Malaysian Consumer's Perceptive Towards Purchasing Organically Produce Vegetable. International Conference on Business and Economic Research, 3-10.

Richard Shepherd, M. M. (Jun 2005). Determinants of Consumer Behaviour Related to Organic Food. Proquest Central, 34(4-5), 352.

Riefer, A., \& Hamm, U. (2008). Changes in Families' Organic Food Consumption. 12th Congress of the European Association of Agricultural Economists - EAAE 2008. Ghent; Belgium.

Robert East, M. W. (2013). Consumer Behaviour: Applications in Marketing. California: SAGE .

Robyn, E., \& Goodwin, B. A. (2008). Using knowledge, attitudes, social norms, past behaviour and perceptions of control to predict undergraduates" intention to incorporate glycaemic index into dietary behaviour. Nutrition and dietetics, 66(1), 54-59. http://dx.doi.org/10.1111/j.1747-0080.2008.01318.x

Rutherford, L. G., \& DeVaney, S. A. (2009). Utilizing the Theory of Planned Behavior to Understand Convenience Use of Credit Cards. Association for Financial Counseling and Planning Education, 488-6687.

Sabiha Kilic, H. C. (December 2011). Consumers' "Brand Personality" Perception of Global Brands in Informational Technology: An Ampirical Research on Hitit University Students. International Journal of Business and Social Science, 2(22).

Salleh, M. M., Ali, S. M., Harun, E. H., Jalil, M. A., \& Shaharudin, M. R. (2010). Consumer's Perception and Purchase Intentions Towards Organic Food Products: Exploring Attitude Among Academician. Canadian Social Science, 6(6), 119-129.

Samsudin, A., Jusoff, K., Zaini, Z. M. M., Musa, M., Khalid, K., Ngali, N., ... Hamid, M. (2011). Customer's Perception Towards Mcdonald's Icon-Based Nutritional Labels. World Applied Sciences Journal 12 (Special Issue On Service Sector Transforms the Economy), 1-07.

Sangkumchaliang, P., \& Huang, W. (2012). Consumers' Perceptions and Attitudes of Organic Food Products in Northern Thailand. International Food and Agribusiness Management Review, 15(1).

Ščasný, M., Urban, J., \& Zvěrinová, I. (2012). What Motivates Czech Consumers to Buy Organic Food? Czech Sociological Review, 48(3), 709-736.

Scott Wysong, S. B. (2012). The Influence of Situational Variables on Brand Personality Choice. International Journal of Marketing Studies, 4(6).

Sekaran, U., \& Bougie, R. (2010). Research Methods for Business: A Skill Building Approach (5th ed.). West Sussex, UK: John Wiley \& Sons Ltd.

Shabnam, S. (July 2013). Proposed Model for Predicting Environmental Purchase Behavior of Consumers. European Academic Research, I(4), 444-466.

Shaharudin, M. R., Pani, J. J., \& Suhardi Wan Mansor, S. J. (2010). Factors Affecting Purchase Intention of Organic Food in Malaysia's Kedah State. Cross-cultural Communication, 6(2), 105-116.

Shaharudin, M. R., Pani, J. J., Mansor, S. W., Elias, S. J., \& Sadek, D. M. (May 2010). Purchase Intention of Organic Food in Kedah, Malaysia: A Religious Overview. International Journal of Marketing Studies, 2(1).

SMEDA. (2006, Dec). Fast Food Restaurant. Retrieved from http://www.smeda.org/

Sophonsiri, S., \& Polyorat, K. (2009). The Impact of Brand Personality Dimensions on Brans Association and Brand Attractiveness: The Case Study of KFC in Thailand. Journal of Global Business \& Technology, 5(2).

Suprapto, B., \& Wijaya, T. (2012). Model of Consumer's Buying Intention towards Organic Food: A Study among Mothers in Indonesian. International Conference on Economics, Business and Marketing Management, 29, 1-8. 
Swann Jr, W. B., Chang-Schneider, C., \& Larsen McClarty, K. (2007). Do People's Self-Views Matter? Self-Concept and Self-Esteem in Everyday Life. American Psychological Association, 62(2), 84-94. http://dx.doi.org/10.1037/0003-066X.62.2.84

Tarkiainen, A., \& Sundqvist, S. (2005). Subjective norms, attitudes and intentions of Finnish consumers in buying organic food. British Food Journal, 107(11), 808-822. http://dx.doi.org/10.1108/00070700510629760

Thompson, K. E., Haziris, N., \& Alekos, P. J. (1994). Attitudes and Food Choice Behaviour. British Food Journal, 96(11), 9-13. http://dx.doi.org/10.1108/00070709410074632

Tirtiroglu, E., \& Elbeck, M. (2008). Qualifying Purchase Intentions Using Queueing Theory. Journal of Applied Quantitative Methods, 3(2), 167-168.

Traci, H., \& Freling, L. P. (2005). An Empirical Analysis of the Brand Personality Effect. The Journal of Product and Brand Management, 14(7), 404-413. http://dx.doi.org/10.1108/10610420510633350

Tsakiridou, E., Boutsouki, C., Zotos, Y., \& Mattas, K. (2008). Attitudes and behaviour towards organic products: An exploratory study. International Journal of Retail \& Distribution Management, 36(2), 158-175. http://dx.doi.org/10.1108/09590550810853093

Tung, S. J., Shih, C. C., Wei, S., \& Chen, Y. H. (2012). Attitudinal inconsistency toward organic food in relation to purchasing intention and behavior: An illustration of Taiwan consumers. British Food Journal, 114(7), 997-1015. http://dx.doi.org/10.1108/00070701211241581

Voona, J. P., Nguib, K. S., \& Agrawalc, A. (2011). Determinants of Willingness to Purchase Organic Food: An Exploratory Study Using Structural Equation Modeling. International Food and Agribusiness Management Review, 14(2).

Williams, B., Onsman, A., \& Brown, T. (2010). Exploratory factor analysis: A five-step guide for novices. Journal of Emergency Primary Health Care (JEPHC), 8(3).

Wysong, S. B. (2007). Putting the "brand" back into store brands: an exploratory examination of store brands and brand personality. Journal of Product \& Brand Management, 16(4), 226-235. http://dx.doi.org/10.1108/10610420710763912

Yangui, A., Font, M. C., \& Gil, J. M. (2013). The effect of food related personality traits and lifestyle orientation on consumer's behavior related to extra virgin olive oil: estimation of an extended hybrid choice model. 4th International Conference of the African Association of Agricultural Economists (pp. 22-25).

Yap, S., \& Fen, N. A. (October 2008). An Extended Model of Theory of Planned Behaviour in Predicting Exercise Intention. International Business Research, 1(4).

Ye, S. (2012). The impact of destination personality dimensions on destination brand awareness and attractiveness: Australia as a case study. Original scientific paper, 60(4), 397-409.

Zakaria, S., \& Wen, L. C. (2012). Relationship between Food Choice Motive and Organic Food Buying Decision: A Conceptual Study. International Journal of Business and Behavioral Sciences, 2(3).

Zakowska-Biemans, S. (2011). Polish consumer food choices and beliefs about organic food. British Food Journal, 113(1), 122-137. http://dx.doi.org/10.1108/00070701111097385

Zhen, J. S. S., \& Mansori, S. (2012). Young Female Motivations for Purchase of Organic Food in Malaysia. International Journal of Contemporary Business Studies, 3(5). 


\section{Appendix}

\begin{tabular}{|c|c|c|c|c|}
\hline $\begin{array}{c}\text { Constructs/ } \\
\text { Cronbach's } \\
\text { value }\end{array}$ & Items & Mean & $\begin{array}{c}\text { Std. } \\
\text { Deviation }\end{array}$ & Sources \\
\hline $\begin{array}{l}\text { Purchase } \\
\text { Intention } \\
(0.84)\end{array}$ & $\begin{array}{l}\text { I intend to purchase organic fast food instead of } \\
\text { conventional ones in the forthcoming month. } \\
\text { I expect to purchase organic fast food instead of } \\
\text { conventional ones in the forthcoming month. } \\
\text { I plan to purchase organic fast food instead of } \\
\text { conventional ones in the forthcoming month. }\end{array}$ & 3.22 & 1.01 & \multirow{2}{*}{$\begin{array}{l}\text { Adapted from Ajzen } \\
\text { I. (2006); Kim, Han } \\
\text { et al. (2010) }\end{array}$} \\
\hline $\begin{array}{l}\text { Subjective Norm } \\
(0.68)\end{array}$ & $\begin{array}{l}\text { Most people who are important to me thinking that } \\
\text { I ... purchase organic fast food instead of } \\
\text { conventional ones in the near future. } \\
\text { I feel under social pressure to purchase organic fast } \\
\text { food instead of conventional ones in the near future. } \\
\text { My friends think that I... purchase organic fast food } \\
\text { instead of conventional ones in the near future. } \\
\text { What my friends think I should do are matters to me. }\end{array}$ & 2.73 & 0.73 & \\
\hline $\begin{array}{l}\text { Constructs/ } \\
\text { Cronbach's } \\
\text { value }\end{array}$ & Items & Mean & $\begin{array}{c}\text { Std. } \\
\text { Deviation }\end{array}$ & Sources \\
\hline $\begin{array}{l}\text { Perceived Control } \\
(0.70)\end{array}$ & $\begin{array}{l}\text { How much control do you have whether you do or do } \\
\text { not purchase organic fast food? } \\
\text { Purchasing of organic fast food or not is completely } \\
\text { up to me. } \\
\text { Purchasing of organic fast food costs too much } \\
\text { money instead of conventional ones. } \\
\text { When I have to costs too much money, I am.....to } \\
\text { purchase organic fast food instead of conventional } \\
\text { ones. }\end{array}$ & 3.19 & 0.78 & $\begin{array}{l}\text { Adapted from Ajzen } \\
\text { I. (2006); Kim, Han } \\
\text { et al. (2010) }\end{array}$ \\
\hline $\begin{array}{l}\text { Sincerity } \\
(0.92)\end{array}$ & $\begin{array}{l}\text { Wholesome } \\
\text { Real } \\
\text { Sincere } \\
\text { Family-orientation } \\
\text { Traditionalism } \\
\text { Friendly }\end{array}$ & 3.28 & 1.00 & \multirow{5}{*}{$\begin{array}{l}\text { Adapted from } \\
\text { Aaker's (1997); } \\
\text { Richard et al. } \\
\text { (1998); Lee, (2009) }\end{array}$} \\
\hline $\begin{array}{l}\text { Excitement } \\
(0.89)\end{array}$ & $\begin{array}{l}\text { Imaginative } \\
\text { Excited } \\
\text { Cool } \\
\text { Unique } \\
\text { Trendy } \\
\text { Up-to-date }\end{array}$ & 3.03 & 0.93 & \\
\hline $\begin{array}{l}\text { Competence } \\
(0.92)\end{array}$ & $\begin{array}{l}\text { Secure } \\
\text { Reliable } \\
\text { Intelligent } \\
\text { Successful } \\
\text { Corporate } \\
\text { Leader }\end{array}$ & 3.09 & 0.98 & \\
\hline $\begin{array}{l}\text { Sophistication } \\
(0.90)\end{array}$ & $\begin{array}{l}\text { Upper-class } \\
\text { Glamorous } \\
\text { Feminine } \\
\text { Smooth } \\
\text { Charming } \\
\end{array}$ & 2.82 & 0.99 & \\
\hline $\begin{array}{l}\text { Ruggedness } \\
(0.87)\end{array}$ & $\begin{array}{l}\text { Outdoorsy } \\
\text { Masculine } \\
\text { Tough } \\
\text { Strong }\end{array}$ & 2.64 & 1.03 & \\
\hline
\end{tabular}




\section{Copyrights}

Copyright for this article is retained by the author(s), with first publication rights granted to the journal.

This is an open-access article distributed under the terms and conditions of the Creative Commons Attribution license (http://creativecommons.org/licenses/by/3.0/). 